\title{
The effect of different enamel surface treatments on microleakage of fissure sealants
}

\begin{abstract}
Asli Topaloglu-Ak ${ }^{1}$, Özant Önçağ ${ }^{1}$, Bülent Gökçe ${ }^{2}$, Berrin Bent ${ }^{1}$
${ }^{1}$ Ege University, School of Dentistry Department of Pedodontics, Bornova Izmir, Turkey

${ }^{2}$ Ege University, School of Dentistry Department of Prosthetic Dentistry Bornova, Izmir, Turkey

Corresponding author: Asli Topaloglu-Ak Ege University School of Dentistry Pedodontics Department Bornova, Izmir, Turkey

PK: 35100

aslitopaloglu@yahoo.com

Tel.: + 905323318133

Fax.: + 902323230325

Received: 29 January 2013

Accepted: 29 April 2013

Copyright (C) 2013 by

Academy of Sciences and Arts of Bosnia and Herzegovina.

Objective. The aim of this study was to evaluate the effects of different techniques of surface treatment on the microleakage of fissure sealants in permanent molar teeth in vitro. Materials and methods. 96 extracted impacted human third molars were randomly divided into 8 surface treatment groups ( $\mathrm{n}=12$ /group) as 1 . Er: YAG laser; (Fidelis II, Fotona, Ljubljana, Slovenia) $(125 \mathrm{mj}, 20 \mathrm{~Hz})$. 2. Er: YAG laser $+37 \%$ $\mathrm{H}_{3} \mathrm{PO}_{4}$ (15s); 3. ER: AG laser $+37 \% \mathrm{H}_{3} \mathrm{PO}_{4}+$ Prime\&Bond NT; 4. Er: YAG laser + G Bond; 5. Er: YAG laser + Prime\&Bond NT; 6. 37\% $\mathrm{H}_{3} \mathrm{PO}_{4} ; 737 \% \mathrm{H}_{3} \mathrm{PO}_{4}+$ Prime \&Bond NT; 8. G Bond. Sealant material (Clinpro, 3M ESPE, Seefeld, Germany), was applied into the fissures and light-cured for 20s with LED (Bluephase C5, Ivoclar-Vivadent, Schaan, Liechtenstein). Specimens were subjected to thermocycling $\left(1000 \times, 5-55^{\circ} \mathrm{C}\right.$, dwell time: $\left.15 \mathrm{~s}\right)$ and immersed in $0.5 \%$ basic fuchsin solution for $24 \mathrm{~h}$ at $37^{\circ} \mathrm{C}$. The samples were sectioned and scored on a 3 point rating scale using a light microscope with a magnification of $\times 20$. One-way analysis of variance was used to analyze data. Multiple comparisons were analyzed using Bonferroni test $(\mathrm{p}=0.05)$. Results. Er:YAG laser showed the highest microleakage scores whereas Er YAG laser $+37 \% \mathrm{H}_{3} \mathrm{PO}_{4}$ showed the lowest. Although $37 \% \mathrm{H}_{3} \mathrm{PO}_{4}$ group showed higher scores than Er:YAG laser $+37 \% \mathrm{H}_{3} \mathrm{PO}_{4}$, the difference was not statistically significant. Conclusion. Etching fissures with phosphoric acid is sufficient prior to fissure sealant application
\end{abstract} E-mail for permission to publish: amabih@anubih.ba
Key words: Fissure sealant, Laser, Preventive dentistry.

\section{Introduction}

Pit and fissure sealants constitute one of the preventive interventions in paediatric dentistry. Their effectiveness for caries management on occlusal surfaces has been documented in numerous clinical studies (1-3). However, their preventive benefits rely directly upon the ability of the sealing material to thoroughly fill pits and fissures so that it remains completely intact. Subsequently, caries development underneath the sealant restoration is avoided (4). However, undetectable caries in fissures and saliva contamination prior to sealant application are two main problems that can lead to poor bonding to enamel. An invasive approach of widening the fissures before sealing application helps the sealant retention (5). Yet, purposeful removal of enamel in a sound tooth may disturb the equilibrium of the fissure system and expose the patient to drilling (6, 7). The latter problem, saliva contamination, is frequently faced after the pretreatment of 
enamel with phosphoric acid to create microporosites for retention. This could occur at the very critical step, when the cotton rolls are changed after rinsing off the etchant. When the microporosites are coated with saliva, the retention and effectiveness of the fissure sealants are jeopardized (8). Several studies have shown the benefits of adding a bonding agent layer between the etched enamel and the sealant to increase the bond strength in the face of moisture and salivary contamination $(9,10)$.

Currently, various enamel treatment procedures are still under discussion for the optimization of fissure sealant penetration. In recent years there has been significant progress in the use of lasers in dentistry. Lasers can be a useful device for dental care in children, particularly for those with dental fear by eliminating stressors such as the sight and sensation of a drill (11). Laser etching does not require tooth isolation. The lasered enamel surface becomes fractured and uneven, which helps the adhesion of resin based materials. Furthermore, laser produces an acid resistant surface, which could avoid secondary caries formation (11-13). With all these beneficial features, this technique seems to be promising in overcoming the problems faced during fissure sealant application. To date, laser etching of fissures prior to fissure sealant application has been investigated in various studies (14-19). However, it is still questionable whether laser etching alone eliminates the need for acid etching of the enamel surface prior to placement of fissure sealants. There is scarce information about the use of laser pretreatment in combination with acid etching and bonding agents in dental literature. Microleakage under fissure sealants is only one of the several ways of assessing the success or failure.

Therefore, the aim of the present study was to assess the effectiveness of different enamel surface treatments on microleakage of fissure sealants applied to sound permanent molars in vitro. The hypothesis of the study was that lasered and/or bonded fissure sealants showed less microleakage than sealants prepared with the acid etching technique.

\section{Materials and methods}

Recently extracted sound impacted third molars were kept in $0.2 \%$ sodium azide solution at a temperature of $4^{\circ} \mathrm{C}$ prior to the study. The fissures were cleaned with a pumice, using a soft brush and air-water jet. Subsequently, fissures were examined at $20 \times$ under a dissecting microscope to exclude ones with cracks, structural defects or incipient caries lesion. A total of 96 teeth were assigned randomly to eight groups $(n=12 /$ each) (Table 1), in which different pretreatments were carried out according to the manufacture's instructions (Table 2).

In the laser groups, occlusal fissures were irradiated with an Er: YAG laser (Fidelis II, Fotona, Ljubljana, Slovenia). Before operation the power output was set at $2.5 \mathrm{~W}$. The pulse energy was set at $125 \mathrm{mj}$ and the repetition rate was $20 \mathrm{~Hz}$. The laser beam was delivered in non-contact mode with the hand piece positioned perpendicularly to the fissures.

After each of the pretreatments, the sealant (Clinpro, 3M ESPE, Seefeld, Ger-

Table1 Different pretreatment of fissures prior to sealant application

\begin{tabular}{ll}
\hline Group & Surface Pretreatment \\
\hline 1 & Er:YAG laser irridation \\
2 & $\begin{array}{l}\text { Er:YAG laser irridation + 37\% orthophoshoric } \\
\text { acid etching }\end{array}$ \\
3 & $\begin{array}{l}\text { Er:YAG laser irridation + 37\% orthophoshoric } \\
\text { acid etching + Prime \&Bond NT }\end{array}$ \\
4 & Er:YAG laser irridation + G Bond \\
5 & $\begin{array}{l}\text { Er:YAG laser irridation + Prime \&Bond NT } \\
6\end{array}$ \\
7 & $\begin{array}{l}37 \% \text { orthophoshoric acid etching } \\
\text { 37\%ond NT }\end{array}$ \\
8 & \begin{tabular}{l} 
Self etching adhesive (G Bond) \\
\hline
\end{tabular}
\end{tabular}


Table 2 Composition and application procedures of etchants and adhesive materials prior to sealing

\begin{tabular}{lll}
\hline Product & Composition & Application \\
\hline $\begin{array}{l}\text { Scotchbond etching gel } \\
\text { (3MESPE; St Paul, MN, USA) }\end{array}$ & $37 \%$ phosphoric acid gel & $\begin{array}{l}\text { Apply and leave for } 30 \mathrm{~s}, \text { rinse } 15 \mathrm{~s}, \\
\text { air dry for } 10 \mathrm{~s} .\end{array}$ \\
$\begin{array}{l}\text { Prime \& Bond NT } \\
\text { (Dentsply De Trey; Konstanz, } \\
\text { Germany) }\end{array}$ & $\begin{array}{l}\text { Di-and trimethacrylate resins, PENTA, nanofillers, } \\
\text { amorphous silicone dioxide, photoinitiators, } \\
\text { stabilizers, cetylamine hydrofluoride, acetone }\end{array}$ & $\begin{array}{l}\text { Apply and leave for } 20 \mathrm{~s}, \text { gently air } \\
\text { dry light cure for } 20 \mathrm{~s} .\end{array}$ \\
& $\begin{array}{l}\text { Acetone, distilled water, } \\
\text { 4-methacryloxyethyltrimellitate anhydride, } \\
\text { urethane dimethacrylate, triethyleneglycol } \\
\text { dimethacrylate }\end{array}$ & $\begin{array}{l}\text { Apply and leave for } 10 \mathrm{~s}, \text { dry } \\
\text { thoroughly under air pressure for } 5 \mathrm{~s} \\
\text { and light cure for } 10 \mathrm{~s} .\end{array}$ \\
\hline
\end{tabular}

many) was applied into the fissures with a tip syringe and spread with a dental probe to prevent air entrapment. The sealant was light-cured for $20 \mathrm{~s}$ using LED (Bluephase C5, Ivoclar Vivadent) with an output of 500 $\mathrm{mw} / \mathrm{cm}^{2}$. All teeth were treated by the same operator. After light curing, the specimens were subjected to thermocycling. The teeth were subjected to a thermocycling regimen of 1000 cycles between $5^{\circ} \mathrm{C}$ and $55^{\circ} \mathrm{C}$ water baths. Dwell time was 15 seconds with a 10 second transfer time between baths. Thereafter, microleakage was assessed by the conventional dye-penetration method. The apices of the teeth were covered with composite to avoid dye penetration, and after that, the whole tooth surface, apart from the area within $2 \mathrm{~mm}$ of the sealant varnish interface. Specimens were then immersed in $0.5 \%$ basic fuchsine solution (Wako Pure Chemical Industry; Osaka, Japan) for 24 $\mathrm{h}$ at $37^{\circ} \mathrm{C}$. Afterwards the specimens were rinsed thoroughly with water and had their roots cut out using a diamond bur. The sealed crowns were embedded in self-curing acrylic resin and sectioned along the buccolingual direction through the mesial, central and distal fissures, resulting in four tooth fragments with six section sides available for inspection. Microleakage was scored by two blinded independent observers, using a light microscope with magnification of $\times 20$ (Leicamicrosystems stereo microscope, Ltd. Stereo and microscope systems; Heerburg, Switzerland). Microleakage per section side was scored on a 3 point rating scale. Score 0 indicated no microleakage visible, score 1 revealed microleakage in up to half of the fissure, while score 2 meant microleakage reaching more than half of the fissure. In case of disagreement between the observers, a third independent observer was consulted to make the final decision. To determine the intra-examination reliability, 10 randomly selected molar fragments were re-evaluated for microleakage. The intra kappa value was found to be 1 by both of the examiners.

\section{Statistical analysis}

Statistical analysis was carried out by using Statistical Packages for Social Sciences (SPSS) 15.0 for Windows. One-way analysis of variance was used to compare the microleakage measures of different groups. Multiple comparisons between groups were analyzed using the Bonferroni test. Statisti$\mathrm{cal}$ analysis was conducted at a significance level of $\mathrm{p}<0.05$.

\section{Results}

The mean microleakage scores and standard deviations of all groups are given in Table 3.

No tooth section was lost during the preparation of the specimens.

All the groups demonstrated microleakage regardless of the surface pretreatments. The lowest microleakage values were obtained in group 2 (laser etching in combi- 
Table 3 Mean microleakage scores and standard deviations (SD) of different enamel pretreatment groups

\begin{tabular}{ll}
\hline $\begin{array}{l}\text { Enamel pretreatment } \\
\text { Groups ( } \mathrm{n}=12 \text { for each group) }\end{array}$ & $\begin{array}{l}\text { Mean microleakage } \\
\text { scores } \pm \text { SD (12 } \\
\text { teeth } \times 6 \text { sides) }\end{array}$ \\
\hline Laser ( $\mathrm{n}=72)$ & $1.30 \pm 1.24^{\mathrm{b}}$ \\
Laser + Acid etching ( $\mathrm{n}=72)$ & $0.23 \pm 0.59^{\mathrm{a}}$ \\
Laser + Acid Etching + Prime \& & $0.43 \pm 0.81^{\mathrm{a}}$ \\
Bond NT ( $\mathrm{n}=72)$ & \\
Laser + G Bond ( $\mathrm{n}=72)$ & $0.27 \pm 0.61^{\mathrm{a}}$ \\
Laser + Prime \& Bond NT ( $\mathrm{n}=72)$ & $1.12 \pm 1.25^{\mathrm{b}}$ \\
Acid etching ( $\mathrm{n}=72)$ & $0.45 \pm 0.78^{\mathrm{a}}$ \\
Acid + Prime\&Bond NT ( $\mathrm{n}=72)$ & $0.80 \pm 1.09^{\mathrm{b}}$ \\
G Bond $(\mathrm{n}=72)$ & $0.83 \pm 1.03^{\mathrm{b}}$
\end{tabular}

a,b $p<0,001$

nation with acid etching). The highest microleakage scoring was observed in group 1 (laser etching). Based on the levels of statistical significance, the following ranking was achieved in terms of lowest to highest microleakage values: Laser + acid etching $=$ laser + GBond $=$ laser + acid etching + Prime\&Bond NT $=$ acid etching $<$ acid etching + Prime\&Bond NT $=$ GBond $=$ laser + Prime\&Bond NT = laser (“<” denotes significantly lower value at $\mathrm{p}<0.001$; and " $=$ " denotes no significant difference at $\mathrm{p}>0.05$ ).

\section{Discussion}

Microleakage in fissure sealants is often faced, unless the material is handled properly and saliva contamination is controlled (20). The latter problem derives from the sensitivity of the technique of placement of fissure sealants (21). The multi-step requirements such as drying, acid etching, rinsing and drying again increase the saliva contamination risk. Many pretreatment protocols have been developed to overcome this problem. One of them was the bonded sealant technique which supported the idea of using an adhesive system prior to sealant applications $(22,23)$. Both in vitro and in vivo studies substantiated the benefits of use of adhesive materials as an intermediate layer under the sealant materials $(9,10)$. With the introduction of self-etching adhesives, this technique has become even more attractive due to the elimination of the separate etching, rinsing and drying steps. Moreover, a reduction in chair time is another advantage for dentists, especially in treating uncooperative children (24).

Laser etching is another alternative to be used with fissure sealant application. It leads to the formation of more stable and less acid soluble compounds, thus reducing susceptibility to secondary caries $(25,26)$. In addition, enamel treatment with laser irradiation is claimed to facilitate the receptiveness to adhesive procedures $(27,28)$. However, in the dental literature there is scarce information about the combined use of laser etching and adhesive systems prior to the placement of resin based sealant material. Microleakage tests are useful methods to evaluate the sealing performance of adhesive systems (29). Dye penetration measurements are the most commonly used techniques. However, in the dental literature, microleakage studies are often quite incomparable due to the different study designs and dye materials used. Various particle sizes of dye materials can affect the dye penetration between the enamel and the resin material, leading to different microleakage results (17). Moshonov et al. (30) reported no microleakage in both laser etched and acid etched samples. They concluded that $1 \%$ methylene blue dye solution might have produced these results because the particle sizes were bigger than other solutions, such as $0.2 \%$ rhodamine, $50 \%$ silver nitrate or $0.5 \%$ basic fuchsine solutions. In the present study, $0.5 \%$ basic fuchsine solution was used to overcome the dye penetration problem. Three parallel cuts were made in the bucco-lingual direction through the mesial, central and distal fissures, resulting in four molar fragments with six section 
sides available for inspection, to increase the reliability of measurements. To date, comparative studies regarding laser etching versus acid etching have yielded conflicting results (30-33). Our results are in line with studies reporting that laser etching does not eliminate the necessity for additional acid etching $(33,34)$, in contrast to those reporting similar etching performance (30). Within the limitations of these in vitro conditions, the current study showed that laser etching alone performed the worst, whereas laser etching in combination with acid etching performed the best among all groups.

However, conventional phosphoric acid was found sufficient to etch the enamel surface to create the required retention of the resin based fissure sealant material.

Based on our results, lasered v. non-lasered fissures prior to application of a total etch adhesive system did not make a significant difference in terms of microleakage. Our finding was supported by Cehreli et al. (35). They reported that the use of Er, Cr: YSGG laser prior to bonded fissure sealant application did not improve microleakage resistance (35). However, laser etching in combination with self-etching adhesive provided less microleakage compared to self etching alone. This may be explained by previous studies, stating the lower bond strengths, greater microleakage and shallow etching patterns of self-etching adhesives $(20,22,36$, 37). It may be suggested that laser etching might promote stronger resistance to microleakage of self etching adhesives.

\section{Conclusion}

Within the limitations of the present study, etching fissures with phosphoric acid was sufficient prior to fissure sealant application. Further studies are required to test the effectiveness of laser pretreatments in preventing microleakage and secondary caries formation under resin based sealant material.
Authors' contributions: Conception and design: ATA, OO, BG, BB; Acquisition of data: ATA, OO, BG, BB; Analysis and interpretation of data: ATA, OO, BG, $\mathrm{BB}$; Drafting the article: ATA, OO, BG, BB; Revising it critically for important intellectual content: ATA, OO, BG, BB.

Conflict of interest: The authors declare that they have no conflict of interest.

\section{References}

1. Weintraub JA. The effectiveness of pit and fissure sealants. J Public Health Dent. 1989;49(5 Spec No):317-30.

2. Hicks MJ, Flaitz C. The acid etch technique in caries prevention: pit and fissure sealants and preventive restorations. In: Pinkham JR, editor. Pediatric Dentistry Infancy Through Adolescence, 3rd edition. Philadelphia: W. B. Saunders; 1999. p. 481-521.

3. Koch G, Poulsen S, Twetman S. Caries prevention in child dental care. In: Koch G, Poulsen S, editors. Pediatric Dentistry: A Clinical Approach. Copenhagen: Munksgaard; 2001. p. 119-45.

4. Simonsen RJ. Retention and effectiveness of a single application of white sealant after 10 years. J Am Dent Assoc. 1987;115(1):31-6

5. Kramer N, Garcia-Godoy F, Lohbauer U, Schneider K, Assmann I, Frankenberger R. Preparation for invasive pit and fissure sealing: air-abrasion or bur? Am J Dent. 2008;21(6):383-7.

6. Clinical guideline on periodicity of examination, preventive dental services, anticipatory guidance, and oral treatment for children. Pediatr Dent. 2004;26(7 Suppl): 81-3.

7. Welbury, R., M. Raadal, and N.A. Lygidakis, EAPD guidelines for the use of pit and fissure sealants. Eur J Paediatr Dent. 2004;5(3):179-84.

8. Silverstone LM, Hicks MJ, Featherstone MJ. Oral fluid contamination of etched enamel surfaces: an SEM study. J Am Dent Assoc. 1985;110(3):329-32.

9. Feigal RJ, Musherure P, Gillespie B, Levy-Polack M, Quelhas I, Hebling J. Improved sealant retention with bonding agents: a clinical study of two-bottle and single-bottle systems. J Dent Res. 2000;79(11):1850-6.

10. Hitt JC, Feigal RJ. Use of a bonding agent to reduce sealant sensitivity to moisture contamination: an in vitro study. Pediatr Dent. 1992;14(1):41-6.

11. Sungurtekin E, Oztas N. The effect of erbium, chromium:yttrium-scandium-gallium-garnet laser etching on marginal integrity of a resin-based fissure sealant in primary teeth. Lasers Med Sci. 2010;25(6):841-7. 
12. Oho T, Morioka T. A possible mechanism of acquired acid resistance of human dental enamel by laser irradiation. Caries Res. 1990;24(2):86-92.

13. Usumez S, Orhan M, Usumez A. Laser etching of enamel for direct bonding with an Er,Cr:YSGG hydrokinetic laser system. Am J Orthod Dentofacial Orthop. 2002;122(6):649-56.

14. Lepri TP, Souza-Gabriel AE, Atoui JA, PalmaDibb RG, Pecora JD, Milori Corona SA. Shear bond strength of a sealant to contaminated-enamel surface: influence of erbium : yttrium-aluminum-garnet laser pretreatment. J Esthet Restor Dent. 2008;20(6):386-92; discussion 393-4.

15. Lupi-Pegurier L, Bertrand MF, Muller-Bolla M, Rocca JP, Bolla M. Comparative study of microleakage of a pit and fissure sealant placed after preparation by Er: YAG laser in permanent molars. J Dent Child (Chic). 2003;70(2):134-8.

16. Hossain M, Yamada Y, Masuda-Murakami Y, Nakamura Y. Removal of organic debris with Er:YAG laser irradiation and microleakage of fissures sealants in vitro. Lasers Med Sci. 2012;27(5):895-902.

17. Youssef MN, Youssef FA, Souza-Zaroni WC, Turbino ML, Vieira MM. Effect of enamel preparation method on in vitro marginal microleakage of a flowable composite used as pit and fissure sealant. Int J Paediatr Dent. 2006;16(5):342-7.

18. Baygin O, Korkmaz FM, Tuzuner T, Tanriver M. The effect of different enamel surface treatments on the microleakage of fissure sealants. Lasers Med Sci. 2012;27(1):153-60.

19. Sancakli HS, Erdemir U, Yildiz E. Effects of Er:YAG laser and air abrasion on the microleakage of a resin-based fissure sealant material. Photomed Laser Surg. 2011;29(7):485-92.

20. Celiberti P, Lussi A. Use of a self-etching adhesive on previously etched intact enamel and its effect on sealant microleakage and tag formation. J Dent. 2005;33(2):163-71.

21. Ganesh M, Shobha T. Comparative evaluation of the marginal sealing ability of Fuji VII and Concise as pit and fissure sealants. J Contemp Dent Pract. 2007;8(4):10-8.

22. Perry AO, Rueggeberg FA. The effect of acid primer or conventional acid etching on microleakage in a photoactivated sealant. Pediatr Dent. 2003;25(2):127-31.

23. Hannig M, Grafe A, Atalay S, Bott B. Microleakage and SEM evaluation of fissure sealants placed by use of self-etching priming agents. J Dent. 2004;32(1):75-81.

24. Pashley DH, Tay FR. Aggressiveness of contemporary self-etching adhesives. Part II: etching effects on unground enamel. Dent Mater. 2001;17(5):430-44.
25. Hicks MJ, Flaitz CM. Epidemiology of dental caries in the pediatric and adolescent population: a review of past and current trends. J Clin Pediatr Dent. 1993;18(1):43-9.

26. Tagomori S, Morioka T. Combined effects of laser and fluoride on acid resistance of human dental enamel. Caries Res. 1989;23(4):225-31.

27. De Munck J, Van Meerbeek B, Yudhira R, Lambrechts P, Vanherle G. Micro-tensile bond strength of two adhesives to Erbium:YAG-lased vs. bur-cut enamel and dentin. Eur J Oral Sci. 2002;110(4):322-9.

28. Eversole LR, Rizoiu I, Kimmel AI. Pulpal response to cavity preparation by an erbium, chromium:YSGG laser-powered hydrokinetic system. J Am Dent Assoc. 1997;128(8):1099-106.

29. Crim GA, Garcia-Godoy F. Microleakage: the effect of storage and cycling duration. J Prosthet Dent. 1987;57(5):574-6.

30. Moshonov J, Stabholz A, Zyskind D, Sharlin E, Peretz B. Acid-etched and erbium:yttrium aluminium garnet laser-treated enamel for fissure sealants: a comparison of microleakage. Int J Paediatr Dent. 2005;15(3):205-9.

31. Gutknecht N, Apel C, Schafer C, Lampert F. Microleakage of composite fillings in Er,Cr:YSGG laser-prepared class II cavities. Lasers Surg Med. 2001;28(4):371-4.

32. Hossain M, Nakamura Y, Yamada Y, Murakami Y, Matsumoto K. Microleakage of composite resin restoration in cavities prepared by Er,Cr:YSGG laser irradiation and etched bur cavities in primary teeth. J Clin Pediatr Dent. 2002;26(3):263-8.

33. Borsatto MC, Corona SA, Ramos RP, Liporaci JL, Pecora JD, Palma-Dibb RG. Microleakage at sealant/enamel interface of primary teeth: effect of Er:YAG laser ablation of pits and fissures. J Dent Child (Chic). 2004;71(2):143-7.

34. Lupi-Pegurier L, Bertrand MF, Genovese O, Rocca JP, Muller-Bolla M. Microleakage of resin-based sealants after Er:YAG laser conditioning. Lasers Med Sci. 2007;22(3):183-8.

35. Cehreli SB, Gungor HC, Karabulut E. Er,Cr:YSGG laser pretreatment of primary teeth for bonded fissure sealant application: a quantitative microleakage study. J Adhes Dent. 2006;8(6):381-6.

36. De Munck J, Van Landuyt K, Peumans M, Poitevin A, Lambrechts P, Braem M, et al. A critical review of the durability of adhesion to tooth tissue: methods and results. J Dent Res. 2005;84(2):118-32.

37. Kanemura N, Sano H, Tagami J. Tensile bond strength to and SEM evaluation of ground and intact enamel surfaces. J Dent. 1999;27(7):523-30. 